\title{
The Predictors of the Willingness to Recommend a Visit for Diversified Tourism Attractions
}

\author{
Miha Lesjak¹, Josef Navrátil' ${ }^{2}$ Kamil Pícha ${ }^{3}$, Vivian L. White Baravalle Gilliam ${ }^{4}$ \\ e-mail: miha.lesjak@turistica.si, josefnav@gmail.com, kpicha@ef.jcu.cz, vivian@mail.vstecb.cz \\ ${ }^{1}$ Faculty of Tourism Studies - Turistica, University of Primorska, Slovenia \\ ${ }^{2}$ Department of Biological Disciplines, Faculty of Agriculture, University of South Bohemia \\ in České Budějovice, Czech Republic \\ ${ }^{3}$ Department of Trade and Tourism, Faculty of Economics, University of South Bohemia \\ in České Budějovice, Czech Republic \\ ${ }^{4}$ Institute of Technology and Business in České Budějovice, Czech Republic
}

Lesjak, M., Navrátil, J., Pícha, K., \& Gilliam, V. L. W. B. (2015). The Predictors of the Willingness to Recommend a Visit for Diversified Tourism Attractions. Czech Journal of Tourism, 4(2), 77-90. DOI: 10.1515/cjot-2015-0005

\begin{abstract}
The predictors of a positive word-of-mouth experience as an important destination loyalty factor among tourist in the Šumava and South Bohemian Touristic Regions were studied via structural equation modelling. The perception of quality, on-site experience, and the perception of value as the mediators between the motivation to visit and the word-of-mouth experience were studied. The pleasant 'natural' environment, the history, the accessibility, and the closeness were found as the pull motivation factors. Social gathering, education, self-reflection, and relaxation were revealed as the push motivation factors. Speaking of the common-place factors, the complexity, the novelty, and the density were all identified as factors of perception of the visited environment. The on-site experience is given by pleasure, arousal, and dominance feelings. The model 'motivation to visit $\rightarrow$ quality of environment $\rightarrow$ on-site experience $\rightarrow$ perceived value of environment $\rightarrow$ satisfaction with visit $\rightarrow$ willingness to recommend the visit' was found as being appropriate for the collected data.
\end{abstract}

\section{Keywords}

motivation, experience, loyalty, quality, Czech Republic

JEL classification: L83, Q26 


\section{Introduction}

Tourists are the most important pillar of tourism development in destinations. They are the consumers of touristic products that give benefits to entrepreneurs and the economy of the destination (Ritchie \& Crouch, 2003). As the competition among the tourism destinations is permanently on the increase (Echtner \& Ritchie, 2003), destinations are forced to maintain the present visitors and attract the new ones as well (Webster \& Ivanov, 2014), together with the increasing pressure on commercialising the remarkable natural and historical attractions. One of the reasons is that the attention of many managers is turned towards the activities related to the support of the image of these destinations (Bonn et al., 2005), in which both the natural and historical attractions play an important part as motivators. One of the most important factors of the destination image is the comparison of this image with the real experience during a visit. This comparison influences the satisfaction with the visit. That satisfaction influences the loyalty to the destination: the willingness to return and the willingness to recommend the visit (Yoon \& Uysal, 2005). The loyalty to a destination becomes a fundamental strategic component for organizations (Chi \& Qu, 2008). The recommendations to other people (via word-of-mouth) are mainly one of the most often sought after types of information for people who are interested in travelling (Hui et al., 2007).

The aim of this paper is to examine the relationship between the presence of natural and historical attractions and destination loyalty.

\section{Theoretical basis}

The willingness to recommend the visit is one of the common measures of the destination loyalty as a further intended action being influenced by the visit to the destination (Chen \& Tsai, 2007). The theory suggests that there should be several hierarchized predictors of the willingness to recommend a visit (= positive word-of-mouth). That is why it is better to determine the relationship between the presence of natural and historical attractions and the destination loyalty via several stages than to make a simple comparison of those two variables - for discussion of this issue consult Denstadli and Jacobsen (2010). First of all, word-of-mouth is the outcome of the satisfaction with a visit; the more positive the satisfaction is, the stronger the willingness to recommend the visit to a destination is (e.g. Bigné et al., 2001). There are several other constructs linking presence of natural and historical attractions and satisfaction with the visit.

Several direct predictors of satisfaction have been found: the perceived value (e.g. He \& Song, 2009); the perceived quality (e.g. Yuan \& Jang, 2008); and the on-site experience (e.g. Bigné et al., 2005; Denstadli \& Jacobsen, 2010). Various ties among the above mentioned constructs (the perceived value, the perceived quality and on site experience) were reported. Most researchers agreed that the perceived value is the best predictor of satisfaction (e.g. Chen \& Tsai, 2007; He \& Song, 2009). The roles of the perceived quality and the on-site experience are still not clear. However, the on-site experience is 
considered to be a mediator between the perceived quality and the perceived value in tourism (e.g. Jang \& Namkung, 2009).

The perceived quality is influenced by the image of the visited site most of all (e.g. Bigné et al., 2001; Chan \& Tsai, 2007). The image is the reason why the visitor comes to the site. He or she visits the sites for certain purposes. These purposes are considered to be motives. The motives can be divided into two distinct groups (Goossens, 2000): those tourists who are pushed to visit a place due to their emotional needs (the so-called "push" motives), and those who are pulled by the benefits the place could offer them (the so-called "pull" motives).

Although there are many ties among the above mentioned constructs, the simplest model is usually needed for a specific practical application. Thus, the following hypothesis has been formed: "It is possible to understand the variability of the willingness to recommend the visit (measured by positive and negative word-of-mouth experience) by the direct non-branched structural model - motivation to visit $\rightarrow$ quality of environment $\rightarrow$ on-site experience $\rightarrow$ perceived value of environment $\rightarrow$ satisfaction with the visit $\rightarrow$ willingness to recommend the visit."

The Šumava Mountains and South Bohemian Tourist Regions (Cetkovský et al., 2007) were chosen as the study areas (Figure 1).

Figure 1: Study area and surveyed localities

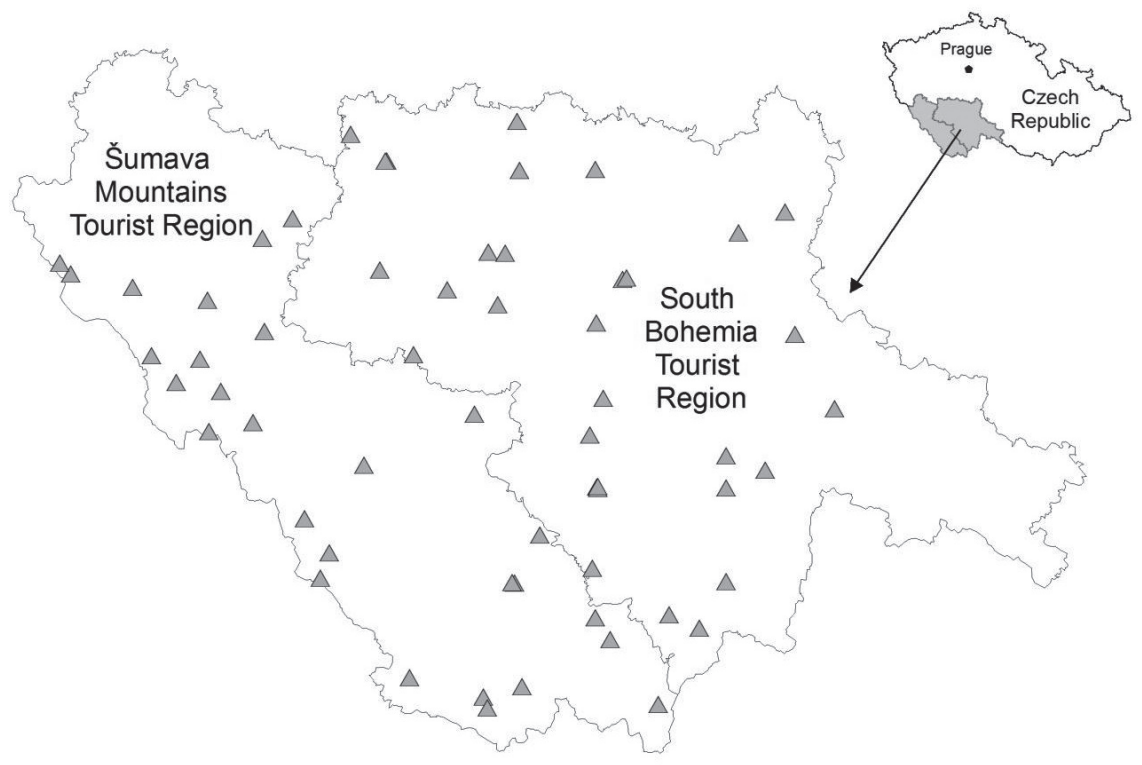

Source: own materials, Czech Statistic Office (2009) 


\section{Methodology}

The data needed to fulfil the set aim and to test the set hypothesis were collected in the field by means of structured interviews with the tourists.

\section{Data collection}

The survey was held during the summer tourist season (from June to September) from 2009 to 2013 throughout the Šumava and South Bohemia Tourist Regions (59 sites, Figure 1) and 3,776 questionnaires were collected. The refusal rate was $15 \%$.

The research was conducted both during the workdays and the weekends to ensure the near random sample. Every visitor was approached due to the circumstances of the low daily volume of visitors. Every fifth visitor was approached in case of the medium volume of visitors. Every tenth visitor was approached in case of the high volume of visitors. The aim was to obtain 64 completed questionnaires from each site.

\section{Questionnaire}

The motivation construct was based on the traditional push and pull motivations. The partial push and pull motives were adapted from previous studies (Petrick et al., 2001; Yoon \& Uysal, 2005). The respondents were asked to rate the importance of 16 push motives and 14 pull motives. The motivation to visit was measured by a five-point Likertlike Scale with " 1 = Not at all important" and " 5 = Very important".

The perception of the quality of the environment of the site was identified by means of the Mehrabian-Russell general measure of information rate. The reason why that scale was used instead of the "classic" quality measure tools is the generality of its use. If one understands quality to be "a measure of the provider's performance" (Petrick, 2004, p. 399), then the quality results from the performance of the environment of the visited place. The corrected 14 seven-point scales of semantic differential by Donovan and Rossiter (1982) and Donovan et al. (1994) were employed.

The main components of the on-site experience are emotions or moods. The leading environmental psychology approach (the Mehrabian-Russell Model) was used for the measurement of the emotions that were experienced in these particular locations. The original 18 three dimensional Pleasure-Arousal-Dominance measures were used (Bakker et al., 2014). The original seven-point scale semantic differential was applied.

These constructs were completed with questions on the perceived value, the satisfaction and the willingness to recommend the visit. The following question was used as a measure of the perceived value: "Was this visit worth your time, money, and effort?" (Chen \& Tsai, 2007), and measured on a five-point Likert Scale ( 1 = Definitely not, $5=$ Definitely yes). As for the measure of satisfaction, the expectation-disconfirmation model was used. The satisfaction was assessed by asking the question: "Overall, how satisfied were you with your visit?” (Yoon \& Uysal, 2005). It was measured on a five-point Likert 
Scale $(1=$ Very Unsatisfied, $5=$ Very Satisfied). In case of the measure of the willingness to recommend the visit, the following question was asked: "Will you suggest this place to your friends/relatives as an excellent place to visit” (Yoon \& Uysal, 2005). It was measured on a five-point Likert Scale ( 1 = Definitely not, $5=$ Definitely yes).

The main segmentation criteria (such as gender, age, education and the type of visit) were also recorded (Table 1).

Table 1 The profile of the respondents $(n=3,776)$

\section{The Sample Characteristics}

Gender

Female

Male

Age

18-25

26-35

36-45

46-55

56-65

66-75

$75+$

Education

Primary

Secondary

Secondary with school-leaving exam

Advanced vocational training

Tertiary (university)

Type of visit

Trip during holiday

Official journey

Visiting relatives

12.40

Travel on or from holiday

Excursion

1.62

Trip from home

28.58

Others

Source: authors' research 2009-2011 


\section{Data analyses}

The factors (indicators) of each multi-item construct (the pull motivation, the push motivation, the quality of the environment, the on-site experience) were first identified by an explorative factor analysis (EFA). In all cases, the Principal Components Analysis Method was employed. Only the factors with an eigenvalue greater than 1 were assessed and the results were varimax rotated (Robinson, 1998). Then the composite mean was calculated for each indicator of each construct, i.e. the average value for indicator (EFA factor) from values of items loaded at least with value of 0.5 on this factor. The reliability for each of the indicators was obtained by using the calculation of a Cronbach's alpha coefficient and the indicators with the value of the alpha coefficient of less than 0.6 were removed from further analysis. This procedure was employed on the basis of Peterson's study (Peterson, 1994).

Then the structural equation modelling was performed to test the hypothetical structure of the constructs. The two-stage structural modelling process was performed and the maximum likelihood of the Estimation Method was used (Schumacker \& Lomax, 2004). First, the measurement model was evaluated by using the Confirmatory Factor Analysis and then the testing of the structural model was performed (Nusair \& Hua, 2010). The chi square/d.f. ratio, root mean square error of approximation (RMSEA), the goodness-of-fit index (GFI), the adjusted goodnessof-fit index (AGFI), the normed fit index (NFI), the non-normed fit index (NNFI), and the comparative fit index (CFI) were used as the measures of the goodness-of-fit indices. The chi square/d.f. rate is commonly used, as the chi square statistic itself is considered by many to be an unrealistic standard (Long \& Perkins, 2003). As the chi square is dependent on a number of observations, the rule of 'close fit' states that chi square/d.f. should be a smaller number than $1+\mathrm{n} / 400$ (Steiger, 2009). The values of the RMSEA lower that 0.05 indicates a very good fit and the values between 0.05 and 0.08 indicate an acceptable fit (Browne \& Cudeck, 1992). The GFI, NFI, NNFI, and CFI have ranges of 0 to 1 and scores 0.90 and above are desirable. As the AGFI corrects the GFI for the number of parameters in the model, the value 0.80 or higher is acceptable (Long \& Perkins, 2003).

\section{Results and Discussion}

Four factors of the pull motives that explain the $52.9 \%$ of the total variability, were identified: a pleasant 'natural' environment, history, accessibility, and closeness (Table 2). The items "the location is situated in an interesting landscape; the environment is pleasant here; It is quiet here; It is a site with interesting nature" were loaded on the factor of a pleasant 'natural' environment (Cronbach's alpha $=0.65)$. The items "the location is culturally/artistically interesting; the location is related to an interesting history; it is a protected heritage site" were loaded on the factor "history" (Cronbach's alpha =0.68). The items "it is on the way that we have planned; the location is accessible" were loaded on the factor "accessibility" (Cronbach's alpha $=0.47$ ). The closeness is a single item 
factor with the only one item "it is quite close to our accommodation or home" loaded with value greater than 0.6 on this factor.

The pull motivations are responsible for the choice of a destination because they represent the specific attractions of the destination (Dann, 1981). Thus, the factors of the pull motivations quite often reflect the specifics of the tourism core resources and the attractions (Ritchie \& Crouch, 2003). The two main factors draw attention to the fact that the attractiveness of a destination given by the core resources is still the most important motivating factor to visit a particular place (Goeldner \& Ritchie, 2012).

Table 2 Factors of pull motivations

\begin{tabular}{|c|c|c|c|c|}
\hline & $\begin{array}{c}\text { pleasant } \\
\text { 'natural' } \\
\text { environment }\end{array}$ & history & accessibility & closeness \\
\hline $\begin{array}{l}\text { Location is situated in an interesting } \\
\text { landscape. }\end{array}$ & 0.693 & & & \\
\hline It is quiet here. & 0.649 & & & \\
\hline It is a site with interesting nature. & 0.626 & & & \\
\hline Environment is pleasant here. & 0.620 & & & \\
\hline Information is provided in this location. & 0.494 & & & \\
\hline $\begin{array}{l}\text { Opportunity to obtain spiritual meaning } \\
\text { through } \\
\text { contact with this place. }\end{array}$ & 0.485 & & & \\
\hline Location is culturally/artistically interesting. & & 0.846 & & \\
\hline Location is related to an interesting history. & & 0.809 & & \\
\hline It is a protected heritage site. & 0.478 & 0.505 & & \\
\hline It is fun here. & & & 0.705 & \\
\hline Location is accessible. & 0.454 & & 0.546 & \\
\hline It is on the way that we have planned. & & & 0.532 & \\
\hline I heard that this place is interesting. & & & 0.431 & \\
\hline It is quite close to our accommodation. & & & & 0.914 \\
\hline eigenvalue & 3.867 & 1.320 & 1.197 & 1.019 \\
\hline$\%$ of total variability (cumulative) & 27.621 & 37.049 & 45.597 & 52.874 \\
\hline
\end{tabular}

Source: authors' research 2009-2011

The four factors of the push motivation to visit were revealed: social gathering, education, self-reflection, and relaxation (Table 3). These four factors explain $50.3 \%$ of variability of the dataset. The items "experience an adventure; to be with friends; to enjoy myself; to meet new people; to talk with friends about our experience during the journey" were loaded on the social gathering factor (Cronbach's alpha $=0.74$ ). The items 
"to visit interesting places; to gain new knowledge; to get to know new locations" were loaded on the educational factor (Cronbach's alpha $=0.60$ ). The items "reflection on site about the good old times; the possibility to be really myself; to be at place that friends have not visited yet" were loaded on the self-reflection factor (Cronbach's alpha $=0.46$ ). The items "to free ourselves of a stereotypical sort of day-to-day life and job; to change the environment" were loaded on the relaxation factor (Cronbach's alpha $=0.55$ ).

Table 3 Factors of push motivations

\begin{tabular}{|c|c|c|c|c|}
\hline & $\begin{array}{c}\text { social } \\
\text { gathering }\end{array}$ & education & $\begin{array}{c}\text { self- } \\
\text { reflection }\end{array}$ & relaxation \\
\hline Be with friends. & 0.787 & & & \\
\hline $\begin{array}{l}\text { Talk with friends after the journey about } \\
\text { experience. }\end{array}$ & 0.700 & & & \\
\hline Enjoy. & 0.621 & & & \\
\hline To meet new people & 0.599 & & & \\
\hline Experience an adventure. & 0.563 & & & \\
\hline Get to know new locations. & & 0.731 & & \\
\hline Gain new knowledge. & & 0.652 & & \\
\hline Visit interesting places. & & 0.630 & & \\
\hline Reflection on site about the "good old times". & & & 0.663 & \\
\hline To be at place that friends did not visited yet. & & & 0.640 & \\
\hline Possibility to be really myself. & & & 0.538 & \\
\hline $\begin{array}{l}\text { Free ourselves of a stereotypical sort } \\
\text { of day-to-day life and job. }\end{array}$ & & & & 0.679 \\
\hline Change environment. & & & & 0.663 \\
\hline Do nothing, just relax. & & & & 0.500 \\
\hline Relax through a physical recreational activity. & & & & 0.426 \\
\hline To be with my family. & & & & 0.393 \\
\hline Eigenvalue & 3.933 & 1.696 & 1.320 & 1.114 \\
\hline$\%$ of total variability (cumulative) & 24.580 & 35.183 & 43.434 & 50.393 \\
\hline
\end{tabular}

Source: authors' research 2009-2011

Social-gathering, which was identified as the first push motivation factor, confirmed the previous findings from the outdoor settings (c.f. Graefe et al., 2000). The following notions of social togetherness and social contact or social gathering are among the main push motives of the participation in travel and tourism (Crompton, 1979). The escape and relaxation factor are among the generally considered push motives towards the participation in travel and tourism (Crompton, 1979; Dann, 1981; Razović \& Tomljenović, 2015) as well as new knowledge and new experience (Graefe et al., 2000; Yoon \& Uysal, 
2005; Ballantyne et al., 2008). The last identified factor (self-reflection) is also counted among the primary push motives (Dann, 1981) as "[t]ravel has always offered a unique opportunity for self-discovery" (Pruitt \& LaFont, 1995, p. 245). In this case, this factor could be considered as a strongly introverted version of self-fulfilment (Hsu et al., 2007).

The four factors of the environment quality perception in this sample (Table 4) were revealed that are quite consistent with the three dimensions discussed by Mehrabian and Russell (1974): being common place, the complexity dimension, novelty, and the spatial dimension. Those four factors explain that $52.3 \%$. The first indicator was labelled as being commonplace because the items such as the usually-surprising factor, the commonrare factor or the similar-contrasting factor were strongly loaded on this factor (Cronbach's alpha $=0.74)$. The second indicator is the complexity dimension because the items given as "continuous-intermittent" and "patterned-random" were strongly loaded on this factor (Cronbach's alpha $=0.61$ ). The third indicator is the novelty with the familiar-novel and the distant-immediate loaded on this factor (Cronbach's alpha $=0.39$ ). The fourth factor is the spatial dimension labelled as the density because the uncrowded-crowded and the sparse-dense items were loaded on this factor (Cronbach's alpha $=0.40$ ).

Table 4 Factors of perceived quality

\begin{tabular}{|c|c|c|c|c|}
\hline & $\begin{array}{l}\text { being common } \\
\text { place }\end{array}$ & complexity & novelty & density \\
\hline usual-surprising & 0.735 & & & \\
\hline common-rare & 0.751 & & & \\
\hline redundant-varied & 0.669 & & & \\
\hline homogeneous-heterogeneous & 0.639 & & & \\
\hline similar-contrasting & 0.587 & & & \\
\hline small scale-large scale & 0.466 & & & \\
\hline simple-complex & 0.488 & & & \\
\hline continuous-intermittent & & 0.796 & & \\
\hline patterned-random & & 0.785 & & \\
\hline symmetrical-asymmetrical & & 0.584 & & \\
\hline immediate-distant & & & 0.786 & \\
\hline familiar-novel & & & 0.755 & \\
\hline uncrowded-crowded & & & & 0.795 \\
\hline sparse-dense & & & & 0.721 \\
\hline eigenvalue & 3.364 & 1.693 & 1.240 & 1.018 \\
\hline$\%$ of total variability (cumulative) & 24.030 & 36.122 & 44.983 & 52.255 \\
\hline
\end{tabular}

Source: authors' research 2009-2011 
Only the first two factors are of importance here. The first one is similar to the novelty (cf. Donovan \& Rossiter, 1982). However, the items of 'complexity' are also present here. Thus, it could represent the 'rarity' factor, i.e., something that is unusual, new, and contrasting at once.

The factor analysis confirmed the original Pleasure (Cronbach's alpha =0.87) - Arousal (Cronbach's alpha = 0.66) - Dominance (Cronbach's alpha =0.68) dimensions explaining $50.1 \%$ of the structure of feelings that had been experienced in particular locations (Table 5). However, the percentage of the explained variability is lower than in the case of analogical studies (Donovan \& Rossiter, 1982; Jang \& Namkung, 2009). As usual, the strongest dimension is the dimension of pleasure (Donovan et al., 1994).

Table 5 Factors of experience

\begin{tabular}{lccc}
\hline & pleasure & arousal & dominance \\
\hline depressed-contented & 0.825 & & \\
unhappy-happy & 0.813 & & \\
annoyed-pleased & 0.800 & & \\
unsatisfied-satisfied & 0.754 & & \\
bored-relaxed & 0.747 & & \\
restricted-free & 0.653 & & \\
despairing-hopeful & 0.598 & & \\
sleepy-widewake & 0.494 & & \\
insignificant-important & 0.396 & 0.741 & \\
calm-excited & & 0.653 & \\
relaxed-stimulated & & 0.625 & \\
sluggish-frenzied & & 0.576 & \\
unaroused-aroused & & 0.531 & 0.788 \\
dull-jittery & & 0.342 & 0.739 \\
uncrowded-overcrowded & & & 0.785 \\
controlled-controlling & & & \\
submissive-dominant & 5.263 & 2.183 & \\
influenced-influential & 29.241 & & \\
eigenvalue & & & \\
\% of total variability (cumulative) & & & \\
\hline
\end{tabular}

Source: authors' research 2009-2011

The pleasant 'natural' environment was used as the motivation measure. Being the commonplace was used as the perception of the environment measure and the pleasure as the on-site experience measure in the final model. The theoretical model has a good fit to the data, except the chi square/d.f. ratio: chi square/d.f. $=14.9$ (based on Steiger 
rule - see Steiger, 2009 - it should be smaller than 10.4), RMSEA = 0.060, GFI = 0.99, $\mathrm{AGFI}=0.97, \mathrm{NFI}=0.98, \mathrm{NNFI}=0.96, \mathrm{CFI}=0.98$. All the structural coefficients are significant (Figure 2). Thus, the model was verified on the data from a variety of sites across the Šmava and South Bohemia Tourist Regions.

Figure 2 Model of willingness to recommend the visit

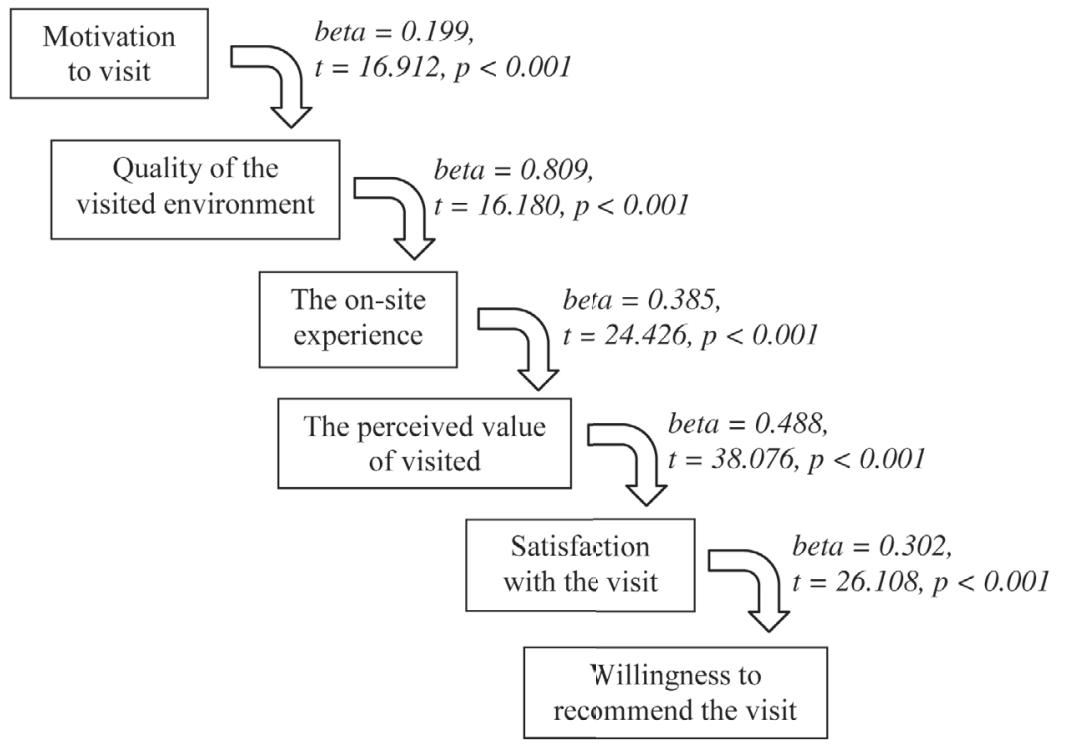

Source: authors' research 2009-2011

\section{Conclusion}

The extent of the positive word-of-mouth experience increases with the higher volume of satisfaction with the visit to the site. The satisfaction is higher if the value that is generated from the visit of the site is higher for the tourist. The perceived value rises with the emotions of pleasure that the visit has evoked in the mind of the visitor. The feeling of pleasure is evoked when something unusual and contrasting can be seen on the site. Finally, the perception of the environment is given by the motivation to spend a pleasurable time in a 'natural' environment. It all means that the positive word-of mouth experience is directly connected to the motivation which stands behind the act of the visit. As the pull motives are formed by the image, the image is compared with the 'reality' with all the consequences during the visit.

As it has been already mentioned in the introduction, many models were proposed to test the context of decision making related to the destination loyalty. However, those models are based on the data obtained from one destination/one place. No model based on the data collected at the complex range of tourist attractions within a destination has 
been tested yet. The advantage of this approach is a wide variety of respondents who differ one from another in many aspects of their tourist behaviour. This could be achieved only when making a survey at many places that differ in the core of their attractiveness. As the research was conducted on many sites, thus yielding a large and representative sample, with completely different tourism core resources, it is valid for the whole area and not only for one type of destination as it is common in similar studies.

Another contribution is the simplicity of the proposed model, which directly focuses on practice rather than on theory. The main research output has marketing management consequences. The issue is that what the visitor expects and what he or she really finds in that place is important as it has a strong and immediate impact on his/her intended future behaviour. The visitor's expectation is given by the image that is formed by each person's own activities of marketing within the tools of marketing promotion. The authors of this study discovered that it was not good to market a false (usually much better) image of the place than the one that was really justified.

\section{References}

Bakker, I., van der Voordt, T., Vink, P., \& de Boon, J. (2014). Pleasure, Arousal, Dominance: Mehrabian and Russell revisited. Current Psychology, 33(3), 405-421. DOI: 10.1007/s12144-0149219-4.

Ballantyne, R., Packer, J., \& Hughes, K. (2008). Environmental awareness, interests and motives of botanic gardens visitors: Implications for interpretive practice. Tourism Management, 29(3), 439-444.

Bigné, J.E., Sanchez, M.I., \& Sanchez, J. (2001). Tourism image, evaluation variable and after purchase behaviour: inter-relationship. Tourism Management, 22(6), 607-616. DOI: 10.1016/S02615177(01)00035-8.

Bigné, J.E., Andreu, L., \& Gnoth, J. (2005). The theme park experience: An analysis of pleasure, arousal and satisfaction. Tourism Management, 26(6), 833-844. DOI: 10.1016/j.tourman.2004.05.006.

Bonn, M.A., Joseph, S.M., \& Dai, M. (2005). International versus domestic visitors: An examination of destination image perceptions. Journal of Travel Research, 43(3), 294-301. DOI: $10.1177 / 0047287504272033$.

Browne, M.W., \& Cudeck, R. (1992). Alternative ways of assessing model fit. Sociological Methods and Research, 21(2), 230-258. DOI: 10.1177/0049124192021002005.

Cetkovský, S., Klusáček, P., Martinát, S., \& Zapletalová, J. (2007). Some aspects of cross-border cooperation in Euroregions of the Czech Republic: An example of the Šumava Region. Moravian Geographical Reports, 15(1), 43-55.

Chen, C., \& Tsai, D. (2007). How destination image and evaluative factors affect behavioral intentions? Tourism Management, 28(4), 1115-1122. DOI: 10.1016/j.tourman.2006.07.007.

Chi, C.G.-Q., \& Qu, H. (2008). Examining the structural relationships of destination image, tourist satisfaction and destination loyalty: An integrated approach. Tourism Management, 29(4), 624-636. DOI: 10.1016/j.tourman.2007.06.007. 
Crompton, J.L. (1979). Motivations of pleasure vacation. Annals of Tourism Research, 6(4), 408-424. DOI: 10.1016/0160-7383(79)90004-5.

Dann, G.M. (1981). Tourism Motivations: An appraisal. Annals of Tourism Research, 8(2), 189-219.

Denstadli, J.M., \& Jacobsen, J.S. (2010). The long and winding roads: Perceived quality of scenic tourism routes. Tourism Management, 32(4), 780-789. DOI: 10.1016/j.tourman.2010.06.014.

Donovan, R.J., \& Rossiter, J.R. (1982). Store atmosphere: An environmental psychology approach. Journal of Retailing, 58(1), 34-57.

Donovan, R.J., Rossiter, J.R., Marcoolyn, G., \& Nesdale, A. (1994). Store atmosphere and purchasing behavior. Journal of Retailing, 70(3), 283-294. DOI: 10.1016/0022-4359(94)90037-X.

Echtner, C.M., \& Ritchie, J.R.B. (2003). The meaning and measurement of destination Image. Journal of Tourism Studies, 14(1), 37-48.

Goeldner, C. R., \& Ritchie, J. R. B. (2012). Tourism: principles, practices, philosophies. Hoboken, NJ: Wiley.

Goossens, C. (2000). Tourism information and pleasure motivation. Annals of Tourism Research, 27(2), 301-321. DOI: 10.1016/S0160-7383(99)00067-5.

Graefe, A.R., Thapa, B., Confer, J.J., \& Absher, J.D. (2000). Relationships between trip motivations and selected variables among Allegheny National Forest visitors. In D.N. Cole, S.F. McCool, W.T. Borrie, \& J. O'Loughlin (Eds.), Wilderness science in a time of change conference - Volume 4: Wilderness visitors, experiences, and visitor management. Missoula, MT: U.S. Department of Agriculture Odgen.

He, Y., \& Song, H. (2009). A mediation model of tourists' repurchase intentions for packaged Tourism services. Journal of Travel Research, 47(3), 317-331. DOI: 10.1177/0047287508321206.

Hsu, C.H.C., Cai, L.A., \& Wong, K.K.F. (2007). A model of senior tourism motivations - Anecdotes from Beijing and Shanghai. Tourism Management, 28(5), 1262-1273. DOI: 10.1016/j.tourman.2006.09.015.

Hui, T.K., Wan, D., \& Ho, A. (2007). Tourists' satisfaction, recommendation and revisiting Singapore. Tourism Management, 28(4), 965-975. DOI: 10.1016/j.tourman.2006.08.008.

Jang, S.C.(S.), \& Namkung, Y. (2009). Perceived quality, emotions, and behavioral intentions: Application of an extended Mehrabian-Russell model to restaurants. Journal of Business Research, 62(4), 451-460. DOI: 10.1016/j.jbusres.2008.01.038.

Long, D.A., \& Perkins, D.D. (2003). Confirmation factor analysis of the sense of community index and development of a brief SCI. Journal of Community Psychology, 31(3), 279-296. DOI: 10.1002/ jcop.10046.

Mehrabian, A., \& Russell, J.A. (1974). An approach to environmental psychology. Cambridge: MIT Press.

Nusair, K., \& Hua, N. (2010). Comparative assessment of structural equation modelling and multiple regression research methodologies: E-commerce context. Tourism Management, 31(3), 314-324. DOI: 10.1016/j.tourman.2009.03.010.

Peterson, R. (1994). A meta-analysis of Cronbach's coefficient alpha. Journal of Consumer Research, 21(2), 381-391. DOI: 10.1086/209405.

Petrick, J.F. (2004). The roles of quality, perceived value and satisfaction in predicting cruise passengers' behavioral intentions. Journal of Travel Research, 42(4), 397-407. DOI: $10.1177 / 0047287504263037$. 
Petrick, J.F., Morais, D.D., \& Norman, W.C. (2001). An examination of the determinants of entertainment vacationers' intentions to revisit. Journal of Travel Research, 40(1), 41-48. DOI: $10.1177 / 004728750104000106$.

Pruitt, D., \& LaFont, S. (1995). For love and money. Romance tourism in Jamaica. Annals of Tourism Research, 22(2), 422-440.

Razović, M., \& Tomljenović, R. (2015). Development model of tourism on Croatian open-sea islands. Tourism, 63(1), 19-36.

Ritchie, J.R.B., \& Crouch, G.I. (2003). The competitive destination: A sustainable tourism perspective. Wallingford/Cambridge: CABI Publishing.

Robinson, G. M. (1998). Methods and techniques in human geography. New York: J. Wiley.

Schumacker, R.E., \& Lomax, R.G. (2004). A beginner's guide to structural equation modelling. Mahwah: Lawrence Erlbaum Associates.

Steiger, J.H. (2009). Measures of fit in structural equation modelling: An introduction. Retrieved July 10, 2010, from <http://www.statpower.net/Content/312/Handout/Measures\%20of\%20Fit\%20 in\%20Structural\%20Equation\%20Modeling.pdf $>$.

Webster, C., \& Ivanov, S. (2014). Transforming competitiveness into economic benefits: Does tourism stimulate economic growth in more competitive destinations? Tourism Management, 40, 137-140. DOI: 10.1016/j.tourman.2013.06.003.

Yoon, Y., \& Uysal, M. (2005). An examination of the effects of motivation and satisfaction on destination loyalty: a structural model. Tourism Management, 26(1), 45-56. DOI: 10.1016/j.tourman.2003.08.016.

Yuan, J., \& Jang, S. (2008). The effects of quality and satisfaction on awareness and behavioral Intentions: Exploring the role of a wine festival. Journal of Travel Research, 46(3), 279-288. DOI: $10.1177 / 0047287507308322$. 